\title{
Speaking from Experience: Today's Cuban Women and Breast Cancer
}

\section{Marta Núñez MS PhD}

\begin{abstract}
Over 2200 new cases of breast cancer are diagnosed annually in Cuba, and a decade ago I became one of them. Late in 2000, I underwent breast cancer surgery at the National Oncology and Radiology Institute in the Cuban capital. My experience-both with the disease and as a sociologist at the University of Havana studying gender relations-serves as the basis for the following essay. The article characterizes today's Cuban women, particularly those of us with or at risk of breast cancer, and describes my own and others' responses to our disease. My aim is to provide insights useful to the physicians, nurses, engineers, physicists, technicians, and service and administrative workers in Cuba's health services who interact with us, whose increased awareness will make us feel more deeply understood and respected. In this context, I also reflect on the Cuban media's portrayal of cancer, with recommendations for dismantling the biases of fatalism and even pity often conveyed.
\end{abstract}

KEYWORDS Cancer, breast cancer, survivorship, physicianpatient relations, professional education, Cuba

\section{INTRODUCTION}

A sociologist, I have kept a journal for the past 11 years to record attitudes towards my own breast cancer as well as those of other women with the disease, its entries constituting the only method of inquiry on which I base my testimony. I wrote very personal assessments: how I plunged into the world of cancer when I was first seen at the intake clinic at the National Oncology and Radiobiology Institute (INOR, the Spanish acronym); when I received a battery of tests to diagnose the type of tumor and develop a treatment plan; about my two admissions at INOR for operations to remove the tumor and lymph nodes; about radiotherapy sessions; and the more than 50 followup appointments I have kept since then. This process of reflection helped me to manage constant panic attacks, and even raised my self-esteem as a woman. In the journal, I also described exchanges with my physician, Dr. Zodilina Valdés, and with medical personnel who attended presentations we made together in four scientific meetings at INOR over the years.

The writing also reflects group interviews of the women I met in the oncology services before and after surgery; later, after discharge, I talked more in depth with some of them individually. At one point I stopped, simply because it was too painful, both for them and for me, to describe experiences of how our children, our partners-if we had them-colleagues and neighbors reacted to our cancer. Only now have I gained the necessary distance to continue this project and undertake a deeper study, although it will never be completely "objective." I have also accumulated scientific, literary and journalistic texts published in Cuba and elsewhere, and statistical data concerning breast cancer in Cuba. I cite only part of this literature here. Finally, I have applied knowledge of Cuban women and their influences on transforming gender relations in Cuba, the main theme of my research since 1985 . Therefore, this testimony constitutes above all a promise of future research.

\section{CUBAN WOMEN WITH OR AT RISK OF BREAST CANCER: WHO ARE WE?}

Over 2200 new cases of breast cancer are diagnosed annually in Cuba,[1] and it is estimated that 1 in 14 women will develop the disease. The highest incidence occurs among women aged 45-65 years and breast cancer is the second leading cause of death in women aged 15-49 and >60 years. [2] The average age of women debuting with the disease is about 50 , near the time of menopause. Thus, life experiences, economic and educational shifts, cultural and social "baggage," combined with the changing role of women in Cuban society, concepts of sexuality, and our use of the country's health services all interact in any description of our generation's susceptibility and reaction to breast cancer.[3]

The majority of Cuban women aged 18-55 years work or study, the proportion of housewives decreasing over the last five decades. Women represent $38 \%$ of the Cuban workforce and $47.3 \%$ in the public sector.[4] Since the job market slowly began opening to women in the 1960s and their participation increased proportionally and continuously from the early 1970s, today's women workers may belong to a second or even a third generation of wage-earning women. That is, they follow a tradition of belonging to households where women spend most of their day outside the home and contribute to family income, with all the burdens and benefits this achievement implies. Women constitute $57 \%$ of all Cuban technicians and professionals, a proportion that reaches $66 \%$ in the civilian public sector.[4] Compared to men, more women graduate from high school (12 ${ }^{\text {th }}$ grade) and university. In fact, higher education is dominated by women, who are $63 \%$ of university students and $66 \%$ of university graduates.[5] These factors have empowered women to make more decisions over their own lives-including both personal and professional choices-and also increased their economic independence.

However, the majority of Cuban women also shoulder the burden of a second shift: they are still most often the primary caregivers for their children and elder dependents in the family. And one third of Cuban homes are headed by women. Thus, greater demands are placed on them outside their paid working hours. By the time they have reached their 50 s, as gender and health specialist $\mathrm{Dr}$ Leticia Artiles observes, they have played "a multiplicity of roles... carrying the excess burdens of their gender that...have earned them the name 'sandwich generation'."[6] These additional burdens often account for health-threatening stress, a risk factor for many chronic diseases, including cancer.

If one considers that life expectancy has increased in Cuba, then as Dr Artiles notes, "... women live a third of their lives after [menopause], most with their physical and mental abilities intact." She adds that their quality of life in this last stage depends on their ability to successfully navigate five critical elements that interact in their daily lives: their concept of menopause and climacteric as a health problem; their biology, reflected in their hormonal adjustment in transitioning to the nonreproductive phase; the imprint of 
their own psychology and life histories; their knowledge, beliefs and myths about menopause; and their individual resources (including material, as well as cultural and social). The appearance of cancer compounds this certainly complex and often difficult transition.

Women's relationship to Cuba's universal, free health services reflects both increased empowerment as decision-makers over their lives, as well as the extra responsibilities and emotional tension in their role as heads or managers of households and caregivers for family members. As a result of these and perhaps other factors, they tend to use health services more often than men. For example, Cuba's low birth rate is evidence of their decision to use contraceptives and family planning services, as well as abortion. Today's Cuban women tend to have only one child, whether because a second pregnancy would interrupt their working lives and economic independence and/or due to separation or divorce.

When it comes to breast cancer, however, women's fears often mean they delay seeking even Cuba's free medical attention when they detect "that small lump" on self-examination. The women I spoke with also mentioned they feared illness taking a toll on their families due to the central role they were playing, or on their professional lives, endangering all they had achieved. At the same time of course, early detection is essential because it not only increases survival rates but also permits less invasive treatments. Waiting only exposes women to any imbalance in the immune system, in which cancer tends to "take off."[3]

So, we found ourselves in the oncology clinic: I was 54 years old when diagnosed with cancer and have since lived through many of the experiences I am describing here. One thing that merits early mention in this essay is my confidence in the health professionals treating me: I have constantly benefited not only from their concern, but also from their skills and knowledge of current breast cancer research in Cuba and abroad.

\section{OUR EMOTIONAL RESPONSES TO CANCER}

I decided to devote the second part of this article to our feelings about breast cancer: I am convinced that only if we and those who care for us are capable of recognizing these feelings can we establish the mutual exchange of knowledge and regard that will help improve our quality of life.

The first emotion is surprise, almost always revealed in the question, "Why me?"

Such astonishment soon turns to panic, since the word "cancer" is perhaps one of the most accursed in any language, connoting to most people a horrible death preceded by lengthy agony. Some repress our panic; others quietly and often tearfully confess it to those closest to us. A new and unexpected tension appears in our lives. We are forced to change plans, to postpone activities, in sum, to make decisions, because it takes at least six months to undergo the usual procedures-surgery, radiation and chemotherapy-and recover from their physical and psychological assaults. I have known mothers to hide the disease to avoid placing an emotional burden on emigrating children, only resuming their oncology treatment later, frequently much too late.

Or, they might decide to hide their cancer treatment from everyone possible. Others thirst for knowledge, asking questions of their doctors and other women who have had breast cancer, combing through books and if they have access, surfing the Internet for answers.

Over the last decade, the sexuality of women with breast cancer has been influenced by the fact that most used contraceptives in their younger years, taking advantage of free, universal family planning programs established by the Ministry of Public Health in 1964. Hence, Cuban women have been able to separate enjoyment of their sexuality from the risk of pregnancy. However, the news of a breast cancer diagnosis alters the ways they previously enjoyed their sexuality. Some experiences are reported in Cuba addressing sexuality in women with breast cancer as part of efforts to improve their quality of life. A study by Izquierdo et al. finds that these women perceive their body image as damaged, resulting in embarrassment, a wish to hide their bodies and avoid intimate relationships, adding, "...female sexual dysfunction [in such cases] includes disorders in desire, excitement, and orgasm."[7]

People around us also react in unpredictable ways when they learn the news. After I told a friend, she kept repeating "it can't be." A few hours later, she invited me to Daniel Barenboim's Havana concert series in which he interpreted Beethoven's nine symphonies. Although I was not particularly knowledgeable about classical music, I enjoyed the concerts so much that-to my surprise-throughout the months when I was recuperating from the surgeries and radiotherapy, I became an assiduous listener of the national classical music radio station. Later, I went back to my usual musical preferences: popular Cuban songs of yesterday and today and soft instrumentals. Another friend was alarmed when she visited me in INOR and saw I was doing a group interview with my cubicle companions. A teacher who was offering a recently-launched TV English course visited me just when my companions and I were being prepped for surgery. We were excited to see her-practically a TV star-and her thoughtful presence helped us relax almost as much as our sedatives.

The strongest emotion, one that will never go away, is fear: fear of dying, of pain and of intolerable reactions to medications; fear of physical decline, especially of losing our hair; fear of dependency on others; fear of not having the necessary economic resources to confront the changes in our lives; and the perennial apprehension of recurrent cancer. We have confessed among ourselves that we would rather die of any other disease.

But human beings' capacity to recover from such blows is so strong that-even though the fears never leave us-we learn to live with them and even closet them behind doors just slightly ajar. In the process, cancer makes many of us take stock of our lives. One friend left a management job that interfered with her professional development and returned to work in her field. Another decided to leave her husband. I changed positions at the university so I could have more time for research and married a wonderful man who didn't flinch when he learned that I had undergone breast cancer surgery. Similarly, many other women addressed some thorny areas of their lives that they had previously let slide.

Our own concerns are so great that we have trouble remembering our luck in not having to take on the enormous costs of often lifelong treatment, faced by women like us and their families in various other countries. In some places, families continue to be billed even after the woman dies. I have met women with breast 
cancer from other countries who are astounded to hear that I have not had to pay anything for my medical care, even though, yes, I tell them I had to take sheets, pillows, towels and even drinking water when I was admitted to hospital.

The emotional bond created between us and our physicians is an essential part of our lives once diagnosed: in fact, my own doctor has become a close friend. As rational an academic as I am-and have tried to be in writing this article-l could not conceive of "living with cancer" without her support. But this is not just a matter of personal chemistry: INOR has practiced a policy-greatly appreciated by women like me-of fostering links between us and our doctors. This tradition helps INOR's staff maintain followup and provide psychological support as well as physical care from the beginning.

Aversion to the pity generated in other people and in ourselves is one of the strongest emotions women with breast cancer feel. For centuries, societies have promoted a culture of compassion toward people with cancer, without acknowledging that no one is immune to it, and that carcinogenic cells live in all human beings.

\section{CANCER AND THE MEDIA}

In this regard, the Cuban media do little to contradict the culture of pity and fear, and in fact contribute to stigmatizing cancer. Obituaries commonly refer to a "long illness," a means of avoiding the accursed " $C$ word", but that increases the fears of those of us with cancer. Our fears are also multiplied by depiction in movies and serials of people with cancer, who die more quickly than usually happens in reality, but with whom we identify nonetheless. At the same time, the media use the word "cancer" to describe evils such as bureaucracy or corruption. Popular parlance contributes to the stigma, when people refer to us by shaking their heads, and simply saying, "ah, she is just so sick." All of these phenomena fuel unwelcome pity.

Cancer is terrible, but so is Alzheimer's; so are strokes that leave people partially or totally paralyzed and may even prevent someone from speaking while their minds continue fully alert. Current cancer survival rates are high, and some cancers are even curable. So please do not use cancer as a metaphor for terrible situations and worst fears, as happened in the Middle Ages with the plague or in the 19th century with tuberculosis. I would suggest to journalists, and indeed to everyone, that the preferred concept is "fighting" this disease: witness the way Latin American leaders recently have approached their cancers without abandoning their demanding political responsibilities.

\section{RECOMMENDATIONS}

As part of their continuing professional education, Cuban health workers should learn more about the women diagnosed with breast cancer and, most importantly, what their most common emotional responses to the disease may be. Thus, they can tailor their efforts more closely to each patient's needs and situation. There are women capable of dealing with any possibility, of a primary or recurrent cancer, and there are others who cannot face these facts. Sociological and psychological assessment of women with cancer is not only the task of social scientists; all health personnel should be trained to deal with these challenges.

Finally, it would be useful to find a better word for us than "patients", because it erects a barrier for effective interaction between us and our medical advisors, locating us as objects rather than subjects. Similarly, I dislike the word "survivors," widely used in North America, because it conveys the idea of constantly living alongside death. But I have yet to find an ideal term.

Meanwhile, we have to promote proactive attitudes among women, encouraging breast self-examination and taking questions to their doctors. This is already being done by various media organizations, but program designers should know that often we ourselves are fearful of finding something worrisome, particularly those of us who have already had cancer. Furthermore, we need to promote among physicians even more patience and awareness to spend more time talking with us during our medical visits. I know heavy workloads make this difficult, so I invite health service managers to consider more effective ways of facilitating these interactions.

I hope my words encourage our health professionals to get to know women with breast cancer a bit better and to relate to us with an approach that integrates psychological, biological and sociological considerations appropriate to the Cuban context. After all, they are the ones who work with us to return us to our lives, and our lives to us. $-1 /$ -

\section{REFERENCES}

1. Hidalgo A. Aplican proyecto cubano de rehabilitación de pacientes con cáncer de mamas en Venezuela [Internet]. Diario Digital La Demajagua. 2011 Jan 20 [cited 2011 Aug 30]. Available from: htpp://www.lademajagua.co.cu /.../12636-aplican-proyecto-cubano-de-rehabilitacion-de-pacientes-con-can cer-de-mama-en-venezuela.html. Spanish.

2. Rodríguez ML, Rodríguez E, Rodríguez LM. Comportamiento del cáncer de mama en la comunidad [Internet]. Monografía.com. [cited 2012 Feb 7] Available from: http://www.monografía.com/trabajo081/comportamineto-cancer-ma ma.shtlm. Spanish.

3. Sierra R. Cáncer de mama, enemigo del cuerpo y del alma [Internet]. SEMlac-Corresponsalia Cuba. 2007 Feb 1 [cited 2012 Feb 7]; [about 1 screen] Available from: http://www.redsemlac-cuba.net/Salud/Cancer-de-mama-en emigo-del-cuerpo-y-del-alma.html. Spanish.

4. Anuario Estadístico de Cuba 2010. Edición 2011 [Internet]. Havana: National Statistics Bureau (CU); 2011 [cited 2012 Feb 7]. Table 7.9 Distribución de la fuerza de trabajo por categoría ocupacional y sexo. Available from: http:www .one.cu/aec2010/20080618tabla_cuadro.htmTabla7.9. Spanish.

5. Anuario Estadístico de Cuba 2010. Edición 2011 [Internet]. Havana: National Statistics Bureau (CU); 2011 [cited 2012 Feb 7]. Table 7.7 Nivel educacional de los ocupados por sexo. Available from: http:www.one.cu/ aec2010/20080618tabla cuadro.htmTabla7.7. Spanish.

6. Artiles L. Nudos críticos y capitales en las mujeres de edad mediana. Rev Sexología Soc. 2010 Dec;16(44):4. Spanish.

7. Izquierdo M, Torres B, González M, Jáuregui U. Sexualidad en un grupo de mujeres cubanas con cáncer. Rev Sexología Soc. 2007 Apr;13(33):20. Spanish.

\section{THE AUTHOR}

Marta Núñez Sarmiento (mnspascual@gmail.com), sociologist with a doctorate in economics. Consultant, Center for International Migration Studies, University of Havana, Cuba.

Submitted: October 1, 2011

Approved for publication: March 24, 2012

Disclosures: None 